\title{
Impacts of the COVID-19 lockdown on air quality and its association with human mortality trends in megapolis Mexico City
}

\section{Gurusamy Kutralam-Muniasamy}

Centro de Investigación y de Estudios Avanzados del Instituto Politécnico Nacional

\section{Fermín Pérez-Guevara}

Centro de Investigación y de Estudios Avanzados del Instituto Politécnico Nacional

Priyadarsi D. Roy Instituto de Geología, Universidad Nacional Autónoma de México (UNAM)

\section{Elizalde-Martínez}

Instituto Politécnico Nacional (IPN), Centro Mexicano para la Producción más Limpia (CMP+L)

V.C. Shruti ( $\nabla$ shrutifrnd@gmail.com )

Instituto Politécnico Nacional (IPN), Centro Mexicano para la Producción más Limpia (CMP+L)

\section{Research Article}

Keywords: Air Pollution, NO2, PM2.5, 03, Traffic, Temperature

Posted Date: October 12th, 2020

DOl: https://doi.org/10.21203/rs.3.rs-90079/v1

License: (c) (i) This work is licensed under a Creative Commons Attribution 4.0 International License. Read Full License

Version of Record: A version of this preprint was published at Air Quality, Atmosphere \& Health on October 28th, 2020. See the published version at https://doi.org/10.1007/s11869-020-00960-1. 
1

2

3

20

\section{Impacts of the COVID-19 lockdown on air quality and its association with human} mortality trends in megapolis Mexico City

3

\section{Gurusamy Kutralam-Muniasamy ${ }^{1}$, Fermín Pérez-Guevara ${ }^{1,2}$, Priyadarsi D. Roy ${ }^{3}$,}

\section{Elizalde-Martínez ${ }^{4}$, V.C. Shruti ${ }^{4 *}$}

${ }^{1}$ Department of Biotechnology and Bioengineering, Centro de Investigación y de Estudios

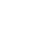

$$
\text { Avanzados del Instituto Politécnico Nacional, Ciudad de México, México }
$$

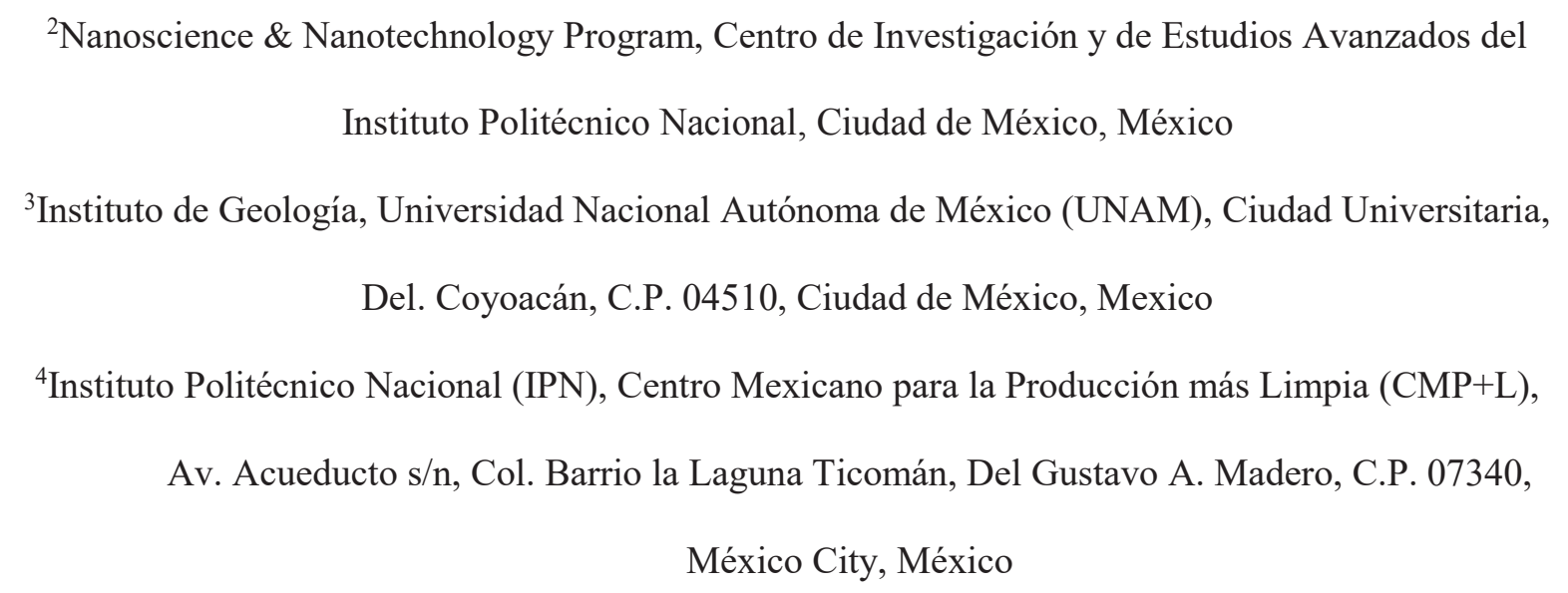

4

5

16

7

18

9

21 *Corresponding Author Mailing Address: Instituto Politécnico Nacional (IPN), Centro Mexicano

22 para la Producción más Limpia $(\mathrm{CMP}+\mathrm{L})$, Av. Acueducto s/n, Col. Barrio la Laguna Ticomán, Del

3 Gustavo A. Madero, C.P. 07340, México, D.F., México.

4 E-mail address: shrutifrnd@gmail.com Tel.: 57296000 Extn- 52612

Keywords: Air Pollution; $\mathrm{NO}_{2} ; \mathrm{PM}_{2.5} ; \mathrm{O}_{3} ;$ Traffic; Temperature. 


\section{Abstract}

27 Mexico City is the second most populated city in Latin America, and it went through

28 two partial lockdowns between April 1 and May 31, 2020 for reducing the COVID-19

29 propagation. The present study assessed air quality and its association with human mortality

30 rates during the lockdown by estimating changes observed in air pollutants $\left(\mathrm{CO}, \mathrm{NO}_{2}, \mathrm{O}_{3}\right.$,

$31 \mathrm{SO}_{2}, \mathrm{PM}_{10}$ and $\mathrm{PM}_{2.5}$ ) between the lockdown (April 1 - May 31) and pre-lockdown (January

32 - March 31) periods, as well as by comparing the air quality data of lockdown period with

33 the same interval of previous five-years (2015-2019). Concentrations of $\mathrm{NO}_{2}(-29 \%), \mathrm{SO}_{2}(-$ $3455 \%)$ and $\mathrm{PM}_{10}(-11 \%)$ declined and the contents of $\mathrm{CO}(+1.1 \%), \mathrm{PM}_{2.5}(+19 \%)$ and $\mathrm{O}_{3}$

$35(+63 \%)$ increased during the lockdown compared to the pre-lockdown period. This study also 36 estimated that $\mathrm{NO}_{2}, \mathrm{SO}_{2}, \mathrm{CO}, \mathrm{PM}_{10}$ and $\mathrm{PM}_{2.5}$ reduced by $19-36 \%$, and $\mathrm{O}_{3}$ enhanced by $14 \%$ 37 compared to the average of 2015-2019. Reduction in traffic as well as less emission from 38 vehicle exhausts led to remarkable decline in $\mathrm{NO}_{2}, \mathrm{SO}_{2}$ and $\mathrm{PM}_{10}$. The significant positive 39 associations of $\mathrm{PM}_{2.5}, \mathrm{CO}$ and $\mathrm{O}_{3}$ with the numbers of COVID-19 infections and deaths, 40 however, underscored the necessity to enforce air pollution regulations to protect human 41 health in one of the important cities of the northern hemisphere.

42

43

44

45 
Introduction

47 Geographical setting (elevated basin surrounded by mountain ridges), climatological

48 conditions and emission of higher amounts of pollutant have led to poor air quality of Mexico

49 City, the second most populated city in Latin America (SMA-GDF 2016; Calderon-

50 Garcidueñas et al. 2015). Different air pollutants are associated with anthropogenic activities

51 like transportation, industry and construction (SMA-GDF 2016; Table 1) and the elevated

52 concentrations of particulate matter $\left(\mathrm{PM}_{10}\right.$ and $\left.\mathrm{PM}_{2.5}\right)$, carbon monoxide $(\mathrm{CO})$ and nitrogen

53 oxides (nitric oxide, $\mathrm{NOx}$ and nitrogen dioxide, $\mathrm{NO}_{2}$ ) during the spring-summer of every

54 year give rise to implementation of the no circulation program (Benítez-García 2014; Molina

55 et al. 2019). Similarly, the concentrations of ozone $\left(\mathrm{O}_{3}\right)$ remain more than the World Health

56 Organization (WHO) recommended 100 microgram per cubic meter in about $79 \%$ of every

57 year. Negative health effects due to air pollution also include specific effects associated with

58 fine particles (Gold et al. 1999; Osornio-Vargas et al. 2003; Calderon-Garcidueñas et al.

59 2015). The government of Mexico City has been implementing the program of No-drive days

60 since 1989 to restrict the circulation of $50 \%$ of privately-owned vehicles and reduce almost

$6120 \%$ of air pollutants for mitigating the deteriorating effects of air pollution on health (Nava

62 Escudero 2008; Davis 2017). Even with the restrictions, the environmental contingency,

63 because of higher levels of $\mathrm{PM}_{10}, \mathrm{PM}_{2.5}$, and $\mathrm{O}_{3}$, has been regular in the months of April to

64 June with additional air pollution coming through forest fire and the agricultural waste

65 combustion in the surrounding states, as well as new vehicles introduced to the system every

66 year (Molina et al. 2019).

67 The rapid spread of COVID-19 to more than 100 countries within three months of its

68 discovery in China prompted the WHO to declare the outbreak as pandemic in March 2020

69 (WHO 2020). Recent reports from several countries like China (Shakoor et al. 2020; Gautam 
70 2020), India (Agarwal et al. 2020; Panda et al. 2020; Sharma et al. 2020), Morocco (Otmani

71 et al. 2020), Brazil (Nakada and Urban 2020), Saudi Arabia (Anil and Alagha 2020), and US

72 (Pata 2020; Doğan et al. 2020) have assessed improvement in the air quality from an

73 appreciable decline in many anthropogenic pollutants in response to restrictions imposed on

74 traffic and industrial activity during the novel coronavirus (SARS-CoV-2) pandemic. In this

75 context, we believe that the estimation of changes in air pollutants from Mexico City is

76 necessary for a global comparison. The new data might even provide important clues for

77 implementing new measures or modification of existing strategies for improving the air 78 quality of one of the polluted cities in Latin America.

79 By August 2020, the COVID-19 death toll from Mexico was the third highest in the 80 world, next to US and Brazil, with the highest confirmed cases ( $\mathrm{n}=95185)$ and deaths 81 ( $\mathrm{n}=8301)$ in Mexico City among all the federal states (https://coronavirus.gob.mx/datos/). In

82 Mexico, the first case of infection was registered on February 28, 2020 and subsequently, all 8332 federal states of Mexico presented COVID-19 cases by March 17, 2020 (Mexico Health 84 Ministry 2020). On March 31, the government of Mexico City announced Sanitary 85 Emergency starting on April 1 as the number of cases exceeded one thousand by March 30, 862020 (Mexico Health Ministry 2020). The first partial lockdown was imposed until April 30

87 and all non-essential activities in the public and private sector, schools and universities were 88 suspended as part of the contention measures. The shopping malls, bars, clubs, zoos, saunas, 89 gyms, and cinemas remained closed and all the individuals over 60 years of age and those 90 with pre-existing medical conditions were instructed to follow the stay-at-home measures. 91 Circulation restrictions (No-drive days) are generally on place all year long, however, on 92 April 23, 2020 an extraordinary scheme was implemented, and the vehicular circulation 93 decreased by $62 \%$ due to the mandatory controls (GDF 2020). In addition, about $20 \%$ of the 
94 metro train, metro bus and light rail stations were closed from April 23, 2020. The

95 government extended the restriction by imposing another period of lockdown until May 31

96 as the number of confirmed cases increased to 5,847 (Mexico Health Ministry 2020). There

97 is no available information about the effects of anthropogenic activities and other sources on

98 overall air quality of Mexico City amid the COVID-19 pandemic. Thus, the main objective

99 of this paper is: (1) to assess the impact of COVID-19 measures on air quality by evaluating

100 the levels of air pollutants, i.e. $\mathrm{CO}, \mathrm{NO}_{2}, \mathrm{O}_{3}, \mathrm{SO}_{2}, \mathrm{PM}_{10}$ and $\mathrm{PM}_{2.5}$, between January 1 - May

10131,2020 and comparing the air quality of the lockdown interval with the same period of

102 previous five years, (2) to evaluate their associations with mobility trends and (3) to

103 empirically analyse whether or not the concentration level of air pollutants can contribute to

104 the outbreak of COVID-19. Therefore, this very first report, as per our knowledge, evaluated

105 the effect of reduced human activities through COVID-19 lockdown on the air quality of

106 Mexico City megapolis.

107 Materials and methods

108 Mexico City is the second most populated city of Latin America with $>21$ million 109 people, divided into 16 municipalities, and circulation of an estimated 9.6 million vehicles 110 (CONAPO 2019). An atmospheric monitoring system, known as SIMAT, continuously 111 measures $\mathrm{O}_{3}, \mathrm{SO}_{2}, \mathrm{NO}_{2}, \mathrm{CO}, \mathrm{PM}_{10}$ and $\mathrm{PM}_{2.5}$ through the manual and automated atmospheric 112 monitoring networks (REDMA and RAMA), atmospheric deposit network (REDDA) and 113 meteorology and solar radiation network (REDMET). The hourly data from RAMA follows 114 the United States Environmental Protection Agency. The daily concentrations (24h) of $\mathrm{SO}_{2}$, $115 \mathrm{NO}_{2}, \mathrm{CO}, \mathrm{PM}_{10}, \mathrm{PM}_{2.5}$ and $\mathrm{O}_{3}$ and meteorological data (i.e. temperature, relative humidity, 116 wind speed and precipitation) were acquired from the official website of atmospheric 117 monitoring system (http://www.aire.cdmx.gob.mx) for the months of January, February, 
118 March, April and May of 2015, 2016, 2017, 2018, 2019 and 2020. We calculated the average 119 of each pollutant $\left(\mu \mathrm{g} / \mathrm{m}^{3}, \mathrm{ppm}\right)$ for each month.

120 We considered the levels of air pollutants between January 1 - March 31, 2020 to 121 represent the air quality of pre-lockdown period. Concentrations of air pollutants of the 122 lockdown period between April 1 - May 31, 2020 were compared with the pre-lockdown 123 concentrations to estimate the short-term changes in air quality during the lockdown period. 124 The lockdown, however, was divided into different periods: PL1 between April 1 - April 30, 1252020 and PL2 between May 1-31, 2020. The Phase I represents changes (\%) occurred in the 126 level of air pollutants of the first period of lockdown, PL1 (i.e. April 1 - April 30, 2020), with 127 respect to pre-lockdown (i.e. January 1 - March 31, 2020). Phase II represents the changes 128 (\%) in air pollutants of the second period of the lockdown, PL2 (May 1 - May 31, 2020) with 129 respect to the first period (PL1) of lockdown. The average concentrations in April and May 130 of 2015-2019 were considered as historical trend and they were compared with air pollutants 131 of the entire lockdown period of 2020 to estimate the long-term changes.

132 To better understand the effects of traffic/mobility on air quality, we acquired online 133 data of average traffic count (https://www.tomtom.com/en gb/traffic-index/mexico-city$134 \underline{\text { traffic/) }}$ for Mexico City by collecting data from TomTom. It represents change in vehicle 135 movements for each day during the COVID-19 pandemic. Basically, the traffic index data is 136 built from users who use TomTom tech in navigation devices, in-dash systems and 137 smartphones. The collected datasets were used to understand the potential relationship 138 between traffic measures and the concentration of air pollutants. We retrieved data of 139 confirmed COVID-19 cases and deaths in Mexico City during the lockdown period from the 140 official website of the Government of Mexico (https://coronavirus.gob.mx/datos/) to find the 141 association between COVID-19 mortality and air pollutants between April 1, 2020 to May 
14231,2020 . Statistica (Version 8) was used to process the data, to perform correlation tests ( $p$

$143<0.05,0.01$ and 0.001$)$ and to determine the relationship between variables.

\section{Results and discussion}

\section{Meteorological parameters of 2015-2020}

146 As the meteorological conditions impact the air quality of a region, we carefully

147 considered the variables of temperature, precipitation, relative humidity and wind speed of 148 the studied interval (i.e. January-May) during 2015-2020 (e.g. Chen et al. 2019). Most of the 149 meteorological conditions of the lockdown period of 2020 and the same interval of previous 150 years were almost similar (Table 2). The average temperature $\left(20-21^{\circ} \mathrm{C}\right)$ of April-May of 1512020 remained almost similar to the average temperature of the previous five years for the 152 same interval $\left(18-22^{\circ} \mathrm{C}\right)$. Average precipitation of the lockdown period $(27 \mathrm{~mm})$ was slightly 153 lower compared to the same months in previous years $(34 \mathrm{~mm})$. The average temperature of 154 the lockdown interval (April-May), however, increased by $4^{\circ} \mathrm{C}$ compared to previous months 155 (January-March) in all the six years. The average temperature of the pre-lockdown period 156 (i.e. January-March between $2015-2020$ ) remained $15-17^{\circ} \mathrm{C}$, and the average temperature of 157 lockdown period (i.e. April-May between $2015-2020$ ) increased to $19-21^{\circ} \mathrm{C}$. The average 158 relative humidity $(42 \%)$ and wind speed $(7.1 \mathrm{mph})$ of the lockdown period exhibited non159 significant variations in comparison with the pre-lockdown period ( $42 \%$ of relative humidity 160 and $7 \mathrm{mph}$ of wind speed). The amount of precipitation during lockdown period, however, 161 was higher compared to the pre-lockdown period (Table 2).

162 Air pollutants during COVID-19 pandemic

Figure 1 shows the mean levels of $\mathrm{PM}_{10}, \mathrm{PM}_{2.5}, \mathrm{NO}_{2}, \mathrm{CO}, \mathrm{SO}_{2}$, and $\mathrm{O}_{3}$ during pre164 lockdown and lockdown periods in Mexico City. The concentrations did not exceed 165 environmental quality standards for air, specified by the Mexican Government (for $\mathrm{PM}_{2.5}=$ 
$16645 \mu \mathrm{g} / \mathrm{m}^{3}, \mathrm{PM}_{10}=75 \mu \mathrm{g} / \mathrm{m}^{3}, \mathrm{SO}_{2}=290 \mathrm{ppm}, \mathrm{NO}_{2}=400 \mathrm{ppm}$ based on 24-hour average, $\mathrm{CO}$ $167=12.5 \mathrm{mg} / \mathrm{m}^{3}$ and $\mathrm{O}_{3}=137 \mathrm{ppm}$ based on 8 -h average) during the lockdown period. 168 Furthermore, all criteria pollutants before lockdown were also within the Mexican air quality 169 standard limits. Our study revealed important changes in concentrations for all air pollutants 170 due to drastic measures adopted to limit the spread of coronavirus during the pandemic. 171 Contents of $\mathrm{NO}_{2}, \mathrm{SO}_{2}$, and $\mathrm{PM}_{10}$ declined during the lockdown period compared to pre172 lockdown (Fig. 1). On the other hand, the concentrations of $\mathrm{O}_{3}$ increased and both $\mathrm{CO}$ and $173 \quad \mathrm{PM}_{2.5}$ fluctuated (Fig. 1).

174 Changes in air quality (percentage) for the period of assessment i.e., lockdown period 175 (April 1 - May 31, 2020) vs pre-lockdown period (January 1 - March 31, 2020) estimated 176 the effectiveness of lockdown on air quality (Fig. 2). $\mathrm{SO}_{2}$ concentration showed a maximum 177 reduction of $55 \%$, and we detected $29 \%$ and $11 \%$ reductions in $\mathrm{NO}_{2}$ and $\mathrm{PM}_{10}$, respectively. 178 By contrast, the concentrations of $\mathrm{O}_{3}, \mathrm{PM}_{2.5}$ and $\mathrm{CO}$ increased during the lockdown period. 179 Most notably, we observed higher augmentation in $\mathrm{O}_{3}(63 \%)$, and the concentrations of $\mathrm{CO}$ 180 and $\mathrm{PM}_{2.5}$ showed increments of $1.1 \%$ and $19 \%$, respectively.

181 Furthermore, we analysed changes in the air quality between two periods of lockdown 182 (Phase I and Phase II) to better understand the influence of COVID-19 pandemic restrictions 183 on air pollutants (Fig. 2). Phase I showed much better air quality with significant reduction 184 in concentrations of pollutants during the first period of lockdown (PL1) with respect to pre185 lockdown. In addition, the reduction (Phase II) in second period of lockdown (PL2) with 186 respect to the first period (PL1) indicated that second period of lockdown was also successful 187 with significant improvement in the air quality. For instance, $\mathrm{SO}_{2}$ and $\mathrm{NO}_{2}$ registered $55 \%$ 188 and $20 \%$ reductions in Phase I, and both showed further reduction of $<10 \%$ in Phase II. In 189 case of $\mathrm{PM}_{10}$, the Phase I registered 1\% reduction and the reduction was still higher in Phase 

II (18\%). However, a fluctuating pattern of $\mathrm{PM}_{2.5}$ showed increase of $21 \%$ in Phase I and 191 decline of 5\% in Phase II. Additionally, we also noted 32\% decline of CO in Phase I and a 192 hike of $98 \%$ during the Phase II. Data in Table 3 shows the change (\%) of air pollutants concentration during the 194 lockdown months of 2020 compared to the historical trend of same interval comprising of 195 previous five years (2015-2019). The $\mathrm{SO}_{2}$ concentration recorded a maximum reduction of $19636 \%$, while $\mathrm{NO}_{2}$ concentration exhibited 33\% reduction. $\mathrm{CO}$ and $\mathrm{PM}_{10}$ concentrations 197 presented almost similar reductions of $29 \%$ and $25 \%$, respectively. Moreover, $\mathrm{PM}_{2.5}$ 198 displayed less reductions (19\%) than other air pollutants. However, the levels of $\mathrm{O}_{3}$ increased 199 by $14 \%$ (Table 3). While significant reductions were reported during lockdown compared to 200 pre-lockdown period of 2020, even much higher reductions in the air pollutants concentration 201 were observed when comparing the lockdown period with the historical trend of 2015-2019. 202 For instance, $\mathrm{NO}_{2}$ and $\mathrm{PM}_{10}$ recorded reductions of $29 \%$ and $11 \%$ during lockdown period 203 and pre-lockdown period, whereas they registered higher reductions of $33 \%$ and $25 \%$ in 204 comparison with five-year trend (2015-2019). Even though CO (1.1\%) and PM2.5 (19\%) were 205 found increased during lockdown and pre-lockdown period, a significant decrease of 29\% 206 and 19\% was observed in comparison to previous five years. Overall, these results clearly 207 indicate that most of the air pollutants significantly decreased during the pandemic compared 208 with the previous five years.

209 In Mexico City, the vehicular emission is the most prominent source of air pollutants, 210 (Table 1). According to the emission inventories of Government of Mexico, the 211 transportation sector contributes more than 5,000 tons of $\mathrm{PM}_{2.5}$ into the atmosphere and $48 \%$ 212 of $\mathrm{PM}_{10}$ (SMA-GDF 2016). The vehicular emission sources account for more than $50 \%$ of 213 air pollutants such as $\mathrm{PM}_{10}, \mathrm{PM}_{2.5}, \mathrm{CO}$ and nitrogen oxides (Table 1) and it is expected that 
214 change in traffic patterns had an important effect on the observed concentrations. Therefore,

215 it is necessary to understand the effect of traffic count on air quality during the COVID-19

216 pandemic. There were 4.6 million cars registered in Mexico City in 2017 and nearly 9.6

217 million in 2019 (CONAPO 2019). During the lockdown period, the vehicular circulation

218 decreased by $62 \%$ due to the mandatory no circulation scheme (GDF 2020). In addition,

219 about $20 \%$ of the metro train, metro bus and light rail stations were closed from April 23,

2202020 (GDF 2020). It is important to mention here that the great majority of population rely

221 heavily on public transportation to commute in Mexico City. In this regard, we assessed the

222 relationship between the traffic count from TomTom database and concentration of air

223 pollutants ( $\mathrm{PM}_{10}, \mathrm{PM}_{2.5}, \mathrm{NO}_{2}, \mathrm{CO}, \mathrm{SO}_{2}$, and $\mathrm{O}_{3}$ ) during the lockdown period (Fig. 3). We

224 observed an immediate change in the traffic volume on April 1, 2020 when the lockdown

225 measures were implemented (Fig. 3 and 4). The daily averaged traffic volume decreased four

226 orders of magnitude in lockdown period compared to the pre-lockdown period, indicating

227 that only fewer people drove and took public transportation to work, while more people

228 stayed at home. This suggests that the measures were effective and widely followed.

229 Furthermore, we performed correlation analysis to explore associations between the

230 air pollutants and vehicular traffic (Fig. 4). The relationship between traffic count and $\mathrm{PM}_{10}$

$231\left(r^{2}=0.33\right), \mathrm{NO}_{2}\left(r^{2}=0.46\right)$ and $\mathrm{SO}_{2}\left(r^{2}=0.30\right)$ confirms that reduced vehicular movements led

232 to a significant reduction in the concentrations of $\mathrm{PM}_{10}(11 \%), \mathrm{NO}_{2}(29 \%)$ and $\mathrm{SO}_{2}(55 \%)$

233 during lockdown period (Fig. 2). Moreover, the positive correlations among $\mathrm{PM}_{10}$ vs $\mathrm{NO}_{2}$

$234\left(r^{2}=0.36\right)$ and $\mathrm{SO}_{2}\left(r^{2}=0.48\right)$ suggest less vehicular emission as the principal reason of better

235 air quality (Table 4). It is important to note that the reduction in $\mathrm{SO}_{2}(55 \%)$ over the entire

236 lockdown period (March 30-May 31, 2020) is comparable to the reduction $(65 \%)$ obtained

237 by limiting the use of sulphur bearing gasoline and diesel oil in 2000-2011 and reduced 
238 emissions from combustion of fossil fuels in industry and power generation plants (Benítez-

239 García 2014). While the traffic patterns could explain some of the trends observed in air 240 quality, they do not explain all the features such as high concentrations of $\mathrm{PM}_{2.5}, \mathrm{CO}$ and $\mathrm{O}_{3}$

241 during lockdown period. In case of $\mathrm{CO}$ and $\mathrm{PM}_{2.5}$, the lack of significant relation with traffic

242 count indicate other sources such as electric energy production and household combustion

243 (SMA-GDF 2016). Certainly, the usage of electric energy and household combustion 244 augmented as people stayed at home and cooked during this global crisis. Regarding $\mathrm{O}_{3}$, we 245 observed negative correlation with traffic count $\left(r^{2}=-0.21\right)$ and strong interactions with $\mathrm{PM}_{2.5}$ $246\left(r^{2}=0.43 ; 0.66 ; 0.60\right)$ for all the three periods (Table 4). Fine aerosols $\left(\mathrm{PM}_{2.5}\right)$ have longer 247 residence times in the atmosphere in comparison with the coarse fraction $\left(\mathrm{PM}_{10}\right)$, and their 248 composition determines how they interact with light (Salcedo et al. 2006; Aiken et al. 2009). 249 Increase in $\mathrm{PM}_{2.5}$ during the Phase I possibly had an impact on optical properties, but it is 250 difficult to know if it was positive or negative without knowing the composition and physical 251 property of aerosol. Similarly, the role of nitrogen oxides and other nitrogenated species in $252 \mathrm{O}_{3}$ production is also complex in the urban atmosphere. In addition, the average temperature 253 of Mexico City during the lockdown interval (April-May) increased by $4^{\circ} \mathrm{C}$ compared to 254 previous months (January-March) of the last six years (Table 2). The strong solar radiations 255 and favourable conditions for photochemical production also lead to peak in $\mathrm{O}_{3}$ levels during 256 the months of April and May (e.g. Chen et al. 2019). Previous intensive campaigns conducted 257 in the Mexico City metropolitan area (i.e., IMADA-AVER, MCMA-2003 and MILAGRO; 258 Song et al. 2010; Palomera et al. 2016) had demonstrated the complexity of atmospheric 259 chemistry in formation of the secondary species like $\mathrm{O}_{3}$ and secondary aerosols. Thus, the 260 increment in both the pollutants during pandemic could be telling something important about 261 changes at the chemistry level. The impacts on air quality due to drastic changes in urban 
262 function during the pandemic would provide valuable information for the air quality

263 management in Mexico City and other cities with similar photochemical pollution problems.

264 Association between COVID-19 and air pollutants

274 Air pollution is a concern in Mexico as it was responsible for one in seventeen (5.9\%)

275 deaths in the country with nearly 48,100 deaths in 2017 (Larsen 2018; Alves 2020). In a

276 previous study in China, Cui et al. (2003) observed high mortality rates in areas with

277 deteriorated air quality during the SARS epidemic, a virus genetically identical to COVID-

278 19. Given that COVID-19 is a respiratory disease that could quickly spread to the community

279 and would remain viable and infectious in aerosols for hours (van Doremalen et al. 2020),

280 this study investigated the association between concentrations of air pollutants and reported

281 daily number of COVID-19 confirmed cases and deaths in Mexico City. At end of the

282 lockdown period, Mexico City reported 29,826 COVID-19 positive cases and 3,676 deaths.

283 About $70 \%(\mathrm{n}=2567)$ of the mortality were represented by men and the rest $30 \%(\mathrm{n}=1109)$

284 were women (Government of Mexico: https://coronavirus.gob.mx/datos/). Figure 3

285 illustrates daily variations in air pollutants and daily reported COVID-19 cases and deaths.

286 Table 4 summarizes the association between air pollutants and the COVID-19 cases and 287 deaths for the entire lockdown as well as in PL1 and PL2. The correlation matrix revealed a 288 significant association between COVID-19 cases and deaths and concentrations of CO and $289 \mathrm{O}_{3}$ for all the three periods. $\mathrm{PM}_{2.5}$, however, showed significant correlations only with cases 290 and mortalities of PL1 and PL2. We observed that the increasing levels of aforementioned 291 air pollutants equally affected the COVID-19 cases and mortality rate, and they were 292 independent of sex. Our results show similarities with other studies conducted in other parts 293 of the world. Most of the countries show substantial relationship between $\mathrm{PM}_{2.5}$ and COVID-

29419 mortality rate. Identical to this study, Xiao et al. (2020) found strong correlation between 
295 both in United States and suggested that the fatality rate can increase up to $15 \%$ by increase 296 in the concentration of $\mathrm{PM}_{2.5}\left(1 \mu \mathrm{g} / \mathrm{m}^{3}\right)$. Similarly, Yao et al. (2020) identified positive 297 association between higher $\mathrm{PM}_{2.5}$ and $\mathrm{PM}_{10}$ and COVID-19 deaths in China. In northern Italy, 298 Setti et al. (2020) recognized strong relationship between both the fine particulate matter and 299 COVID-19 mortality rate. Our study also shows strong positive correlations $\left(r^{2}=0.86 ; 0.65\right)$ 300 of CO with COVID-19 cases and deaths in Mexico City. Pansini and Fornacca (2020) 301 observed that the level of $\mathrm{CO}$ in the air was positively related with the number of infections 302 in Italy, the USA, and China. Alike to our study, Zhu et al. (2020) reported the association 303 between $4.76 \%$ increase in daily confirmed cases in China and $\mathrm{O}_{3}\left(10 \mu \mathrm{g} / \mathrm{m}^{3}\right)$ enhancement. 304 Overall, these evidences indicate air pollutants as a potential risk factor for respiratory 305 infections and increase in COVID-19 confirmed cases and deaths.

\section{Limitations of the study}

Among the limitations of this study, (i) the emission inventories could not be examined to evaluate the impacts from changed patterns, change in fuel consumption at industrial and domestic levels due to lack of data. A thorough analysis of air pollution with respect to emission during the lockdown would be required in the future research. (ii) We 317 people gathering and social distancing for evaluating the relationship between daily COVID-

31819 confirmed cases and deaths. This could be the first study that provides evidence about the 
319 association between air pollutants and COVID-19 mortality in Mexico City. The future

320 studies should consider these limitations as an opportunity in order to establish mechanisms

321 to improve the air quality.

\section{Conclusion}

323 This paper examined the implications of restrictions imposed during two different

324 periods of partial lockdown to mitigate the propagation of COVID-19 on the air quality of 325 Mexico City (Mexico). Contents of $\mathrm{NO}_{2}, \mathrm{SO}_{2}, \mathrm{PM}_{10}$ reduced and ozone was enhanced during

326 the lockdown period compared to the pre-lockdown period as well as historical average of 327 the same interval of last five years. The observed variations in air pollutants did not show 328 association with meteorological parameters and they were mainly caused by stringent 329 restrictions on anthropogenic activities during the COVID-19 pandemic. For example, $\mathrm{NO}_{2}$, $330 \mathrm{SO}_{2}$ and $\mathrm{PM}_{10}$ showed strong relationships with traffic count, indicating significant effect of 331 vehicular movements on air quality. The air pollutants mostly diminished during the first 332 period of lockdown (PL1) between April 1 - April 30, 2020 and the air quality further 333 improved in second period of the lockdown (PL2). Furthermore, $\mathrm{PM}_{2.5}, \mathrm{CO}$ and $\mathrm{O}_{3}$ were 334 significantly correlated with the confirmed COVID-19 cases and deaths. Future studies can 335 provide insight about the inter-regional response towards COVID-19 pandemic and deliver 336 a better understanding of air quality and the spread of COVID-19. We also assume that the 337 air pollutants would intensify once the lockdown restrictions are lifted and this temporary 338 improvement in air quality might help to formulate new strategies to revoke the years of 339 damages caused by different human activities.

340 Acknowledgements

341 VCS thanks CONACYT project no. 274276 "Fase I De La Remediación de Áreas 342 Contaminadas Con Hidrocarburos En La Refinería Gral. Lázaro Cárdenas” for Postdoctoral 
343 fellowship. The authors would like to acknowledge all the health-care workers involved in

344 the diagnosis and treatment of patients world-wide. We also thank Dirección de Monitoreo

345 Atmosférico-CDMX for making air quality data open access.

346 References

347 Agarwal A, Kaushik A, Kumar S, Mishra R (2020) Comparative study on air quality status 348 in Indian and Chinese cities before and during the COVID-19 lockdown period. Air 349 Qual Atmos Health 1-12

350 Aiken AC, Salcedo D, Cubison MJ, Huffman JA, DeCarlo PF, Ulbrich IM, Docherty KS, 351 Sueper D, Kimmel JR, Worsnop DR, Trimborn A (2009) Mexico City aerosol 352 analysis during MILAGRO using high resolution aerosol mass spectrometry at the 353 urban supersite (T0)-Part 1: Fine particle composition and organic source $354 \quad$ apportionment. Atmos Chem Phys 9:6633-6653

355 Alves B (2020) Mexico: deaths from air pollution 2000-2017 Energy \& Environmental 356 Services https://wwwstatistacom/statistics/868758/number-deaths-air-pollution357 mexico/

358 Anil I, Alagha O (2020) The impact of COVID-19 lockdown on the air quality of Eastern 359 Province, Saudi Arabia. Air Qual Atmos Health 1-12

360 Benítez-García SE, Kanda I, Wakamatsu S, Okazaki Y, Kawano M (2014) Analysis of $361 \quad$ criteria air pollutant trends in three Mexican metropolitan areas. Atmosphere 5:806$362 \quad 829$

363 Calderón-Garcidueñas L, Kulesza RJ, Doty RL, D'Angiulli A, Torres-Jardón R (2015) 364 Megacities air pollution problems: Mexico City Metropolitan Area critical issues on 365 the central nervous system pediatric impact. Environ Res 137:157-169 
366 Chen Z, Zhuang Y, Xie X, Chen D, Cheng N, Yang L, Li R (2019) Understanding long-term

367 variations of meteorological influences on ground ozone concentrations in Beijing

368 During 2006-2016. Environ Pollut 245:29-37

369 CONAPO (2019) Consejo Nacional de Población Datos Abiertos del Indice de Marginacion.

370 http://wwwconapogobmx/es/CONAPO/Datos_Abiertos_del_Indice_de_Marginacio

$371 \quad n$

372 Cui Y, Zhang ZF, Froines J, Zhao J, Wang H, Yu SZ (2003) Air pollution and case fatality

373 of SARS in the People's Republic of China: an ecologic study. Environ Health 2:15

374 Davis LW (2017) Saturday driving restrictions fail to improve air quality in Mexico City. Sci

$375 \quad \operatorname{Rep} 7: 41652$

376 Doğan B, Jebli MB, Shahzad K, Farooq TH, Shahzad U (2020) Investigating the Effects of

377 Meteorological Parameters on COVID-19: Case Study of New Jersey, United States.

$378 \quad$ Environ Res 110148

379 Gautam S (2020) COVID-19: air pollution remains low as people stay at home. Air Qual $380 \quad$ Atmos Health 13:853-857

381 GDF (2020) Nuevas medidas para la fase 3 por COVID-9. 382 https://wwwcdmxgobmx/portal/articulo/nuevas-medidas-para-la-fase-3-por-covid-9

383 Gold DR, Damokosh AI, Pope III CA, Dockery DW, McDonnell WF, Serrano P, Retama A, 384 Castillejos M (1999) Particulate and ozone pollutant effects on the respiratory 385 function of children in southwest Mexico City. Epidemiology 8-16

386 Larsen B (2018) Mexico Perspective: Air Pollution Post 2015 CONSENSUS 387 https://wwwcopenhagenconsensuscom/sites/default/files/mexico_resources_air_poll $388 \quad$ utionpdf 
389 Mexico Health Ministry (2020) Nuevo Coronavirus en el mundo COVID-19 Comunicado

390 Técnico Diario. https://wwwgobmx/salud/prensa/nuevo-coronavirus-en-el-mundo-

$391 \quad$ covid-19-comunicado-tecnico-diario-236595

392 Molina LT, Velasco E, Retama A, Zavala M (2019) Experience from integrated air quality

393 management in the Mexico City metropolitan area and Singapore. Atmosphere

$394 \quad 10: 512$

395 Nakada LYK, Urban RC (2020) COVID-19 pandemic: Impacts on the air quality during the 396 partial lockdown in São Paulo state, Brazil. Sci Total Environ 139087

397 Nava Escudero C (2008) From homo sapiens to homo automobilis: Revisiting air quality 398 management in Mexico City. Boletín mexicano de derecho comparado 41:245-278

399 Osornio-Vargas ÁR, Bonner JC, Alfaro-Moreno E, Martínez L, García-Cuellar C, Ponce-de-

400 León Rosales S, Miranda J, Rosas I (2003) Proinflammatory and cytotoxic effects of

401 Mexico City air pollution particulate matter in vitro are dependent on particle size and

402 composition. Environ Health Perspect 111:1289-1293

403 Otmani A, Benchrif A, Tahri M, Bounakhla M, El Bouch M, Krombi MH (2020) Impact of

404 Covid-19 lockdown on PM10, SO2 and NO2 concentrations in Salé City $405 \quad$ (Morocco). Sci Total Environ 139541

406 Palomera MJ, Álvarez HB, Echeverria RS, Hernández EG, Álvarez PS, Villegas RR (2016)

407 Photochemical assessment monitoring stations program adapted for ozone precursors 408 monitoring network in Mexico City. Atmósfera 29:169-188

409 Panda S, Mallik C, Nath J, Das T, Ramasamy B (2020) A study on variation of atmospheric 410 pollutants over Bhubaneswar during imposition of nationwide lockdown in India for 411 the COVID-19 pandemic. Air Qual Atmos Health 1-12 
412 Pansini R, Fornacca D (2020) COVID-19 higher induced mortality in Chinese regions with 413 lower air quality. medRxiv https://doiorg/101101/2020040420053595

414 Pata UK (2020) How is COVID-19 affecting environmental pollution in US cities? Evidence 415 from asymmetric Fourier causality test. Air Qual Atmos Health 1-7

416 Salcedo D, Onasch TB, Dzepina K, Canagaratna MR, Zhang Q, Huffman JA, DeCarlo PF, 417 Jayne JT, Mortimer P, Worsnop DR, Kolb CE (2006) Characterization of ambient 418 aerosols in Mexico City during the MCMA-2003 campaign with Aerosol Mass 419 Spectrometry: results from the CENICA Supersite Atmos Chem Phys 6:925-946 420 Setti L, Passarini F, De Gennaro G, Barbieri P, Perrone MG, Piazzalunga A, Borelli M, 421 Palmisani J, Di Gilio A, Piscitelli P, Miani A (2020) The Potential Role of Particulate 422 Matter in the Spreading of COVID-19 in Northern Italy: First Evidence-Based 423 Research Hypotheses. $424 \quad$ https://www.medrxiv.org/content/10.1101/2020.04.11.20061713v1

425 Shakoor A, Chen X, Farooq TH, Shahzad U, Ashraf F, Rehman A, e Sahar N, Yan W (2020) 426 Fluctuations in environmental pollutants and air quality during the lockdown in the 427 USA and China: two sides of COVID-19 pandemic. Air Qual Atmos Health 1-8

428 Sharma M, Jain S, Lamba BY (2020) Epigrammatic study on the effect of lockdown amid 429 Covid-19 pandemic on air quality of most polluted cities of Rajasthan (India). Air $430 \quad$ Qual Atmos Health 1-9

431 SMA-GDF (2016) Inventario de emisiones de la CDMX Contaminantes criterio, toxicos y 432 compuestos de efecto invernadero. Secretaría del Medio Ambiente Gobierno del 433 Distrito Federal, México DF 
434 Song J, Lei W, Bei N, Zavala M, De Foy B, Volkamer R, Cardenas B, Zheng J, Zhang R, 435 Molina LT (2010) Ozone response to emission changes: a modeling study during the 436 MCMA-2006/MILAGRO Campaign. Atmos Chem Phys 10:3827-3846

437 van Doremalen N, Bushmaker T, Morris DH, Holbrook MG, Gamble A, Williamson BN, 438 Tamin A, Harcourt JL, Thornburg NJ, Gerber SI, (2020) Aerosol and surfacestability 439 of SARS-CoV-2 as compared with SARS-CoV-1. New Engl J Med 382:1564-1567

440 WHO (2020) https://wwwwhoint/emergencies/diseases/novel-coronavirus-2019

441 Xiao Wu, Rachel CN, Sabath MB, Braun D, Xiao FD (2020) Exposure to air pollution and 442 COVID-19 mortality in the United States: a nationwide cross-sectional study. 443 medRxiv https://doiorg/101017/CBO9781107415324004

444 Yao Y, Pan J, Wang W, Liu Z, Kan H, Meng X, Wang W (2020) Spatial correlation of 445 particulate matter pollution and death rate of COVID19/China/PM25. PM10/multiple $446 \quad$ linear regression medRxiv https://doi.org/10.1101/2020.04.07.20052142

447 Zhu Y, Xie J, Huang F, Cao L (2020) Association between short-term exposure to air 448 pollution and COVID-19 infection: evidence from China. Sci Total Environ $449 \quad 727: 138704$

$450 \quad$ Figure legends

451 Figure 1 Average concentrations of air pollutants during the pre-lockdown and two different 452 periods of partial lockdown (PL1 and PL2) in Mexico City (Mexico).

453 Figure 2 Bar chart representing the overall changes (\%) in air pollutants of Mexico City.

454 Figure 3 Daily trends of air pollutants, traffic counts and COVID-19 confirmed cases and 455 deaths since the start of restrictions in Mexico City. 
456 Figure 4 Traffic counts for the period of January 1-May 31, 2020 in Mexico City from the 457 TomTom traffic database and the correlation between traffic count and air pollutants during 458 the lockdown period.

\section{Table legends}

460 Table 1 Main sources of air pollutants for Mexico City (Mexico) according to emission 461 inventory report of SMA-GDF (2016).

462 Table 2 Meteorological parameters of Mexico City (Mexico) from January to May 20154632020.

464 Table 3 Comparison of changes in air pollutants for April and May in 2020 (lockdown 465 period) and the same intervals during 2015-2019 in Mexico City (Mexico).

466 Table 4 Correlation between daily confirmed COVID-19 cases and deaths and air pollutants 467 in Mexico City (Mexico). 
Table 1. Main sources of air pollutants for Mexico City (Mexico) according to emission inventory report of SMA-GDF (2016).

\section{Pollutant sources $\quad$ Contribution of emissions (\%)}

\begin{tabular}{|c|c|c|c|c|c|}
\hline & $\mathrm{PM}_{10}$ & $\mathrm{PM}_{2.5}$ & $\mathrm{SO}_{2}$ & $\mathrm{CO}$ & NOx \\
\hline $\begin{array}{l}\text { Point source } \\
\text { e.g. chemical, food, textile, metal and } \\
\text { mineral based industries and electrical energy } \\
\text { generation }\end{array}$ & 8.3 & 12.9 & 9.3 & 0.3 & 3.6 \\
\hline $\begin{array}{l}\text { Area source } \\
\text { e.g. combustion, urban solid waste, } \\
\text { construction, non-highway vehicles, paved } \\
\text { roads and others }\end{array}$ & 35.1 & 29.5 & 62.6 & 13.3 & 10.1 \\
\hline $\begin{array}{l}\text { Mobile source } \\
\text { e.g. Motorcycles, aircraft operation, SUVs, } \\
\text { vehicles }>3.8 \mathrm{t} \text {, minibuses, industrial } \\
\text { combustions, taxis, buses, tractor trucks, } \\
\text { private cars, }\end{array}$ & 52.5 & 55.7 & 28.1 & 86.4 & 86.1 \\
\hline Agriculture activity & 4.1 & 1.9 & $\mathrm{~N} / \mathrm{A}$ & N/A & 0.2 \\
\hline
\end{tabular}


Table 2: Meteorological parameters of Mexico City (Mexico) from January to May 2015-2020.

\begin{tabular}{|c|c|c|c|c|}
\hline & Temperature $\left({ }^{\circ} \mathrm{C}\right)$ & Relative humidity (\%) & Wind speed (mph) & Precipitation $(\mathrm{mm})$ \\
\hline \multicolumn{5}{|l|}{2015} \\
\hline January & 14 & 54 & 6.1 & 0.3 \\
\hline February & 15 & 45 & 6.1 & 2.9 \\
\hline March & 16 & 54 & 7.3 & 19.5 \\
\hline April & 20 & 48 & 7.0 & 8.3 \\
\hline May & 18 & 61 & 7.4 & 69.6 \\
\hline \multicolumn{5}{|l|}{2016} \\
\hline January & 14 & 45 & 6.0 & 6.7 \\
\hline February & 15 & 41 & 6.3 & 0.8 \\
\hline March & 17 & 42 & 7.8 & 27.8 \\
\hline April & 20 & 38 & 6.8 & 19 \\
\hline May & 20 & 51 & 7.5 & 51.8 \\
\hline \multicolumn{5}{|l|}{2017} \\
\hline January & 15 & 42 & 5.9 & 0 \\
\hline February & 17 & 36 & 7.2 & 0 \\
\hline March & 17 & 44 & 7.7 & 18.1 \\
\hline April & 20 & 35 & 8.0 & 12.9 \\
\hline May & 21 & 46 & 7.5 & 48.9 \\
\hline \multicolumn{5}{|l|}{2018} \\
\hline January & 13 & 48 & 6.3 & 7.9 \\
\hline February & 17 & 47 & 6.3 & 7.7 \\
\hline March & 19 & 39 & 7.1 & 12.2 \\
\hline April & 19 & 44 & 7.9 & 44.5 \\
\hline May & 20 & 46 & 8.1 & 59.1 \\
\hline \multicolumn{5}{|l|}{2019} \\
\hline January & 15 & 46 & 5.8 & 5.3 \\
\hline February & 18 & 40 & 6.4 & 5.7 \\
\hline March & 19 & 38 & 6.9 & 7.2 \\
\hline April & 20 & 35 & 7.4 & 4.3 \\
\hline May & 22 & 37 & 7.9 & 21.6 \\
\hline \multicolumn{5}{|l|}{2020} \\
\hline January & 15 & 47 & 6.5 & 11.3 \\
\hline February & 18 & 41 & 7.5 & 5.3 \\
\hline March & 20 & 38 & 7.0 & 8.1 \\
\hline April & 21 & 41 & 7.1 & 21.9 \\
\hline May & 20 & 43 & 7.1 & 32.8 \\
\hline
\end{tabular}


Table 3. Comparison of changes in air pollutants for April and May in 2020 (lockdown period) and the same intervals during 2015-2019 in Mexico City (Mexico).

\begin{tabular}{cccc}
\hline Air pollutant & $\mathbf{2 0 1 5 - 2 0 1 9}$ & $\mathbf{2 0 2 0}$ & \multicolumn{2}{c}{$\begin{array}{c}\text { Relative change (\%) } \\
\mathbf{( 2 0 1 5 - 2 0 1 9} \text { vs 2020) }\end{array}$} \\
\hline $\mathrm{CO}(\mathrm{ppm})$ & 0.60 & 0.43 & -29 \\
\hline $\mathrm{NO}_{2}(\mathrm{ppm})$ & 0.026 & 0.017 & -33 \\
\hline $\mathrm{O}_{3}(\mathrm{ppm})$ & 0.038 & 0.044 & +14 \\
\hline $\mathrm{PM}_{10}\left(\mu \mathrm{g} / \mathrm{m}^{3}\right)$ & 50.89 & 38.17 & -25 \\
\hline $\mathrm{PM}_{2.5}\left(\mu \mathrm{g} / \mathrm{m}^{3}\right)$ & 28.82 & 23.34 & -19 \\
\hline $\mathrm{SO}_{2}(\mathrm{ppm})$ & 0.0041 & 0.0026 & -36
\end{tabular}

Values in negative shows decreased contents and positive shows increased contents compared to the historical trend (2015-2019). 
Table 4. Correlation between daily confirmed COVID-19 cases and deaths and air pollutants in Mexico City (Mexico).

\begin{tabular}{|c|c|c|c|c|c|c|c|c|c|c|c|c|}
\hline & $\begin{array}{c}\text { Total } \\
\text { number } \\
\text { of cases }\end{array}$ & Female cases & $\begin{array}{l}\text { Male } \\
\text { cases }\end{array}$ & $\begin{array}{l}\text { Total number } \\
\text { of mortality }\end{array}$ & $\begin{array}{c}\text { Female } \\
\text { mortality }\end{array}$ & $\begin{array}{c}\text { Male } \\
\text { mortality }\end{array}$ & $\mathrm{PM}_{2.5}$ & $\mathrm{PM}_{10}$ & $\mathrm{CO}$ & $\mathrm{O}_{3}$ & $\mathrm{NO}_{2}$ & $\mathrm{SO}_{2}$ \\
\hline \multicolumn{13}{|c|}{ Entire lockdown period (April 1-May 31, 2020) } \\
\hline Total number of cases & 1.00 & & & & & & & & & & & \\
\hline Female cases & $0.81^{*+\ddagger}$ & 1.00 & & & & & & & & & & \\
\hline Male cases & $0.51^{*+}$ & $0.40^{* \dagger}$ & 1.00 & & & & & & & & & \\
\hline Total number of mortality & $0.99^{*+\hbar}$ & $0.80^{* \dagger+}$ & $0.52^{* \dagger+}$ & 1.00 & & & & & & & & \\
\hline Female mortality & $0.84^{* \dagger \ddagger}$ & $0.76^{* \dagger \ddagger}$ & $0.60^{* *+}$ & $0.84^{* \dagger \ddagger}$ & 1.00 & & & & & & & \\
\hline Male mortality & $0.86^{*+\hbar}$ & $0.79^{* *}$ & $0.55^{*+1}$ & $0.85^{* \dagger+}$ & $0.82^{*+\hbar}$ & 1.00 & & & & & & \\
\hline $\mathrm{PM}_{2.5}$ & - & - & - & - & - & - & 1.00 & & & & & \\
\hline $\mathrm{PM}_{10}$ & $-0.38^{* \dagger}$ & $-0.29^{*}$ & - & $-0.39^{* \dagger}$ & $-0.44^{* *+}$ & $-0.46^{* * t}$ & $0.81^{* \dagger \ddagger}$ & 1.00 & & & & \\
\hline $\mathrm{CO}$ & $0.86^{* \dagger+}$ & $0.84^{* \dagger \ddagger}$ & $0.47^{* * \dagger}$ & $0.86^{* \dagger \ddagger}$ & $0.88^{* \dagger \neq}$ & $0.84^{* \dagger+}$ & - & $-0.39^{* \dagger}$ & 1.00 & & & \\
\hline $\mathrm{O}_{3}$ & $0.49^{*+}$ & $0.56^{* \dagger}$ & $0.54^{*}+$ & $0.49^{* \dagger \neq}$ & $0.51^{*+\neq}$ & $0.48^{*+1}$ & $0.43^{* \dagger}$ & - & $0.53^{*}+\frac{1}{+1}$ & 1.00 & & \\
\hline $\mathrm{NO}_{2}$ & - & - & $-0.32^{*}$ & - & - & - & $0.48^{*+\neq}$ & $0.36^{* \dagger}$ & - & - & 1.00 & \\
\hline $\mathrm{SO}_{2}$ & - & - & - & - & - & - & $0.37^{* \dagger}$ & $0.48^{* \dagger \ddagger}$ & - & - & - & 1.00 \\
\hline \multicolumn{13}{|c|}{ PL 1 (April 1-April 30, 2020) } \\
\hline Total number of cases & 1.00 & & & & & & & & & & & \\
\hline Female cases & $0.85^{*+\hbar}$ & 1.00 & & & & & & & & & & \\
\hline Male cases & $0.49^{*}$ & - & 1.00 & & & & & & & & & \\
\hline Total number of mortality & $0.99^{*+\ddagger}$ & $0.83^{* \dagger \ddagger}$ & $0.50^{*}$ & 1.00 & & & & & & & & \\
\hline Female mortality & $0.86^{*+\hbar}$ & $0.76^{* \dagger \ddagger}$ & - & $0.87^{* \dagger \ddagger}$ & 1.00 & & & & & & & \\
\hline Male mortality & $0.87^{*+\ddagger}$ & $0.75^{*+\hbar}$ & - & $0.87^{* \dagger+}$ & $0.67^{*+\hbar}$ & 1.00 & & & & & & \\
\hline $\mathrm{PM}_{2.5}$ & $0.44^{*}$ & $0.41^{*}$ & - & $0.45^{*}$ & - & $0.40^{*}$ & 1.00 & & & & & \\
\hline $\mathrm{PM}_{10}$ & - & - & - & - & $0.29^{\dagger}$ & - & $0.85^{*+1}$ & 1.00 & & & & \\
\hline $\mathrm{CO}$ & $0.65^{*+\ddagger}$ & $0.49^{*}$ & - & $0.65^{*+\hbar}$ & $0.57^{*}$ & $0.64^{*}+$ & $0.53^{* \dagger}$ & - & 1.00 & & & \\
\hline $\mathrm{O}_{3}$ & $0.44^{*}$ & $0.43^{*}$ & - & $0.42^{*}$ & - & $0.52^{* \dagger}$ & $0.66^{*+1}$ & $0.42^{*}$ & - & 1.00 & & \\
\hline $\mathrm{NO}_{2}$ & - & - & - & - & - & - & - & - & $0.54^{* \dagger}$ & - & 1.00 & \\
\hline $\mathrm{SO}_{2}$ & - & - & - & - & - & - & $0.53^{*}$ & $0.50^{*}$ & - & - & - & 1.00 \\
\hline \multicolumn{13}{|l|}{ PL 2 (May 1-May 31, 2020) } \\
\hline Total number of cases & 1.00 & & & & & & & & & & & \\
\hline Female cases & $0.43^{*}$ & 1.00 & & & & & & & & & & \\
\hline Male cases & - & - & 1.00 & & & & & & & & & \\
\hline Total number of mortality & $0.99^{*+1}$ & $0.42^{*}$ & - & 1.00 & & & & & & & & \\
\hline Female mortality & - & - & - & - & 1.00 & & & & & & & \\
\hline Male mortality & $0.46^{*}$ & - & - & $0.46^{*}$ & - & 1.00 & & & & & & \\
\hline $\mathrm{PM}_{2.5}$ & $0.40^{*}$ & $0.45^{*}$ & - & $0.39^{*}$ & $0.41^{*}$ & - & 1.00 & & & & & \\
\hline $\mathrm{PM}_{10}$ & - & - & - & $0.44^{*}$ & - & - & $0.86^{* \dagger \ddagger}$ & 1.00 & & & & \\
\hline $\mathrm{CO}$ & $0.39^{*}$ & $0.53^{* \dagger}$ & - & $0.38^{*}$ & $0.38^{*}$ & - & $0.77^{* \dagger \ddagger}$ & $0.72^{*+*}$ & 1.00 & & & \\
\hline $\mathrm{O}_{3}$ & - & $0.44^{*}$ & $0.45^{*}$ & - & $0.40^{*}$ & - & $0.60^{* \dagger \ddagger}$ & $0.66^{*+1}$ & $0.47^{* \dagger}$ & 1.00 & & \\
\hline $\mathrm{NO}_{2}$ & - & $0.64^{* \dagger+}$ & $-0.37^{*}$ & - & - & - & $0.67^{* \dagger \ddagger}$ & $0.60^{*+1}$ & $0.89^{* \dagger+}$ & - & 1.00 & \\
\hline $\mathrm{SO}_{2}$ & - & - & - & - & - & - & - & $0.38^{*}$ & - & - & - & 1.00 \\
\hline
\end{tabular}



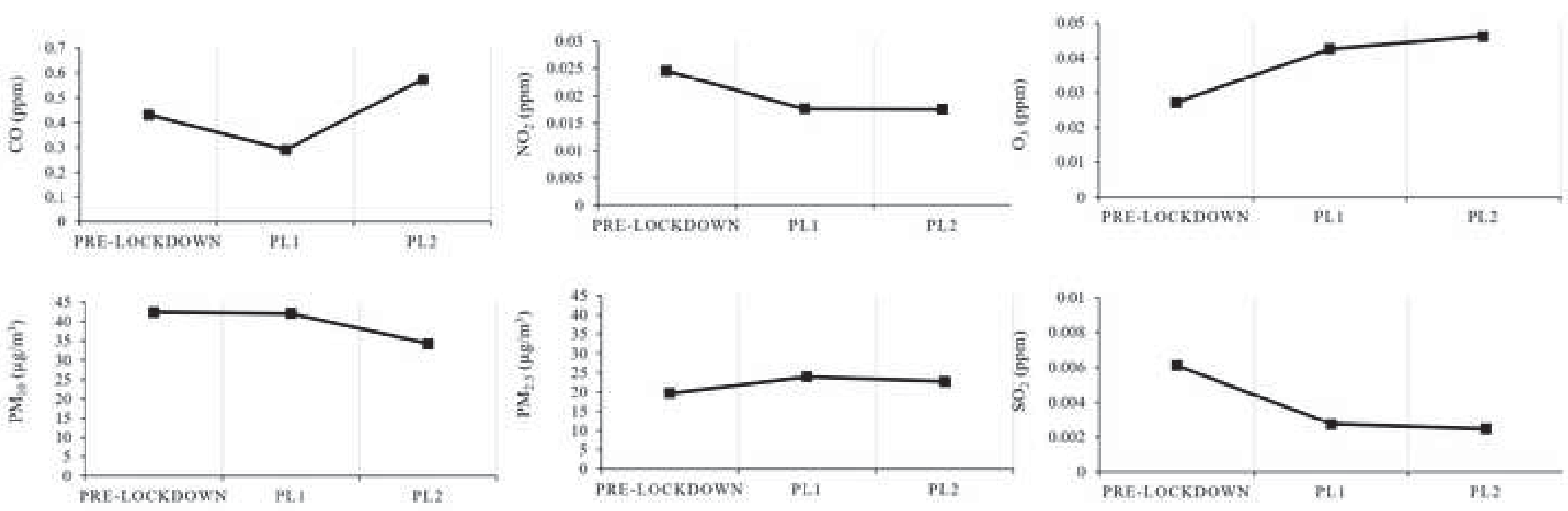

PRE-LOCKDOWN: January 1-Manch 31, 2020

PL1: April 1-April 30, 2020

PL2: May 1-May 31, 2020 


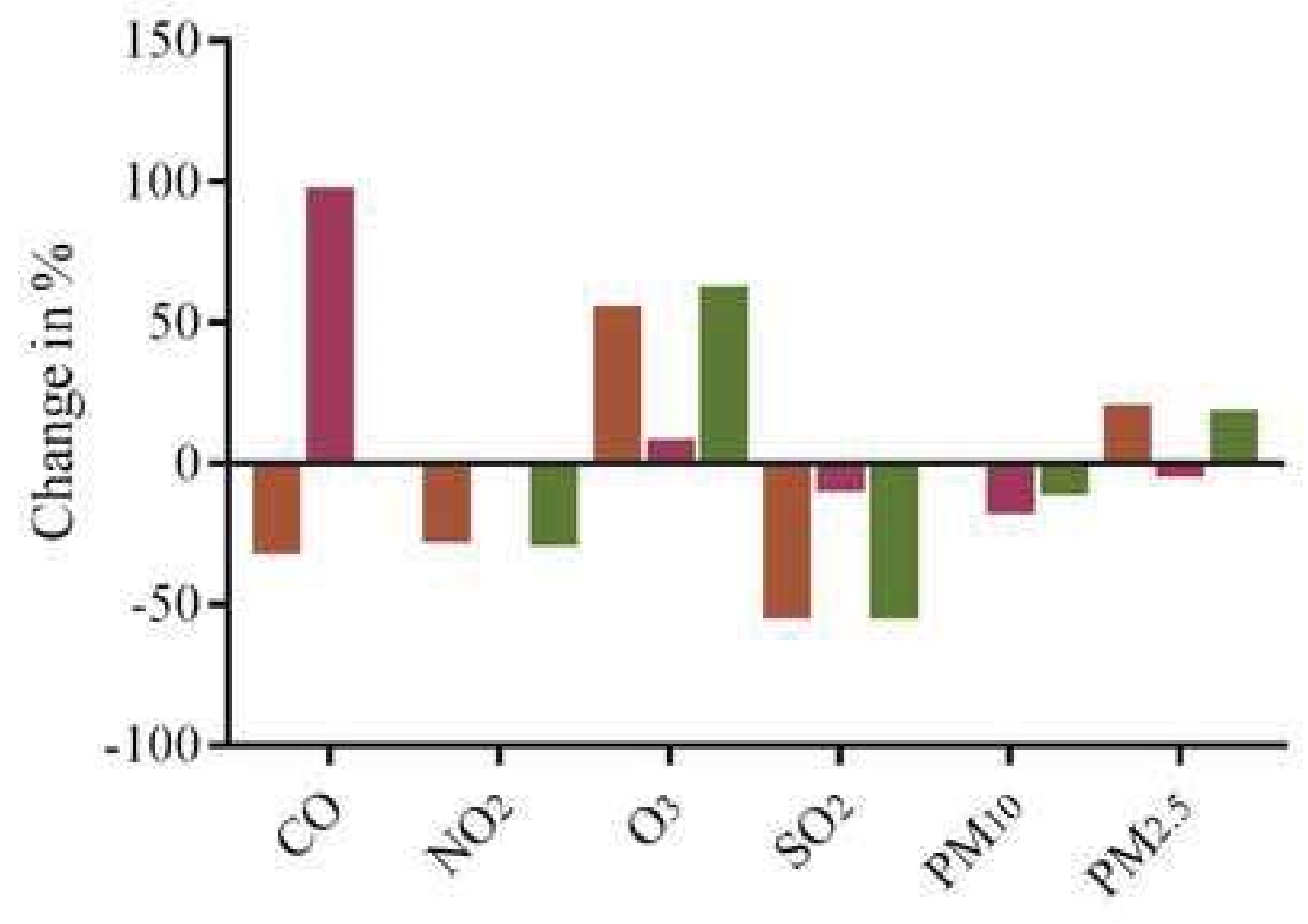

- Phase I

Chase II

- Pre-lockdown vs Lockdown 


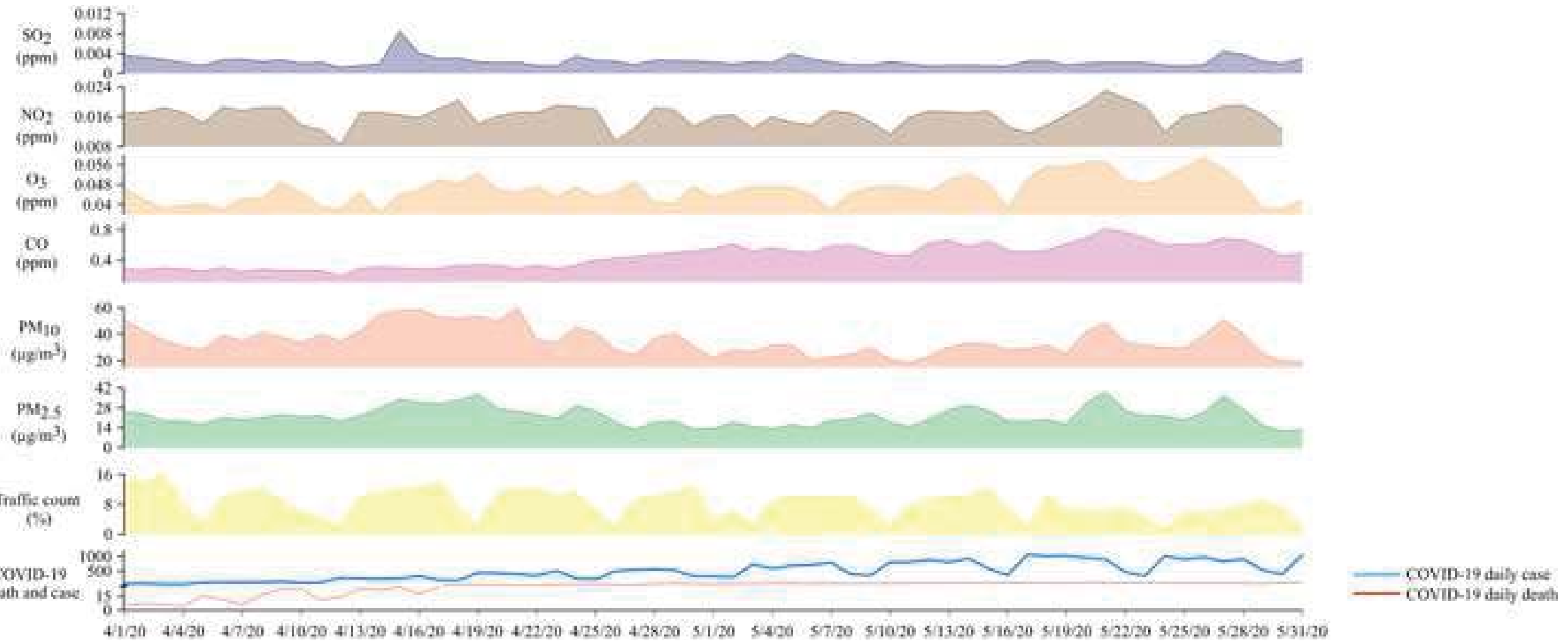




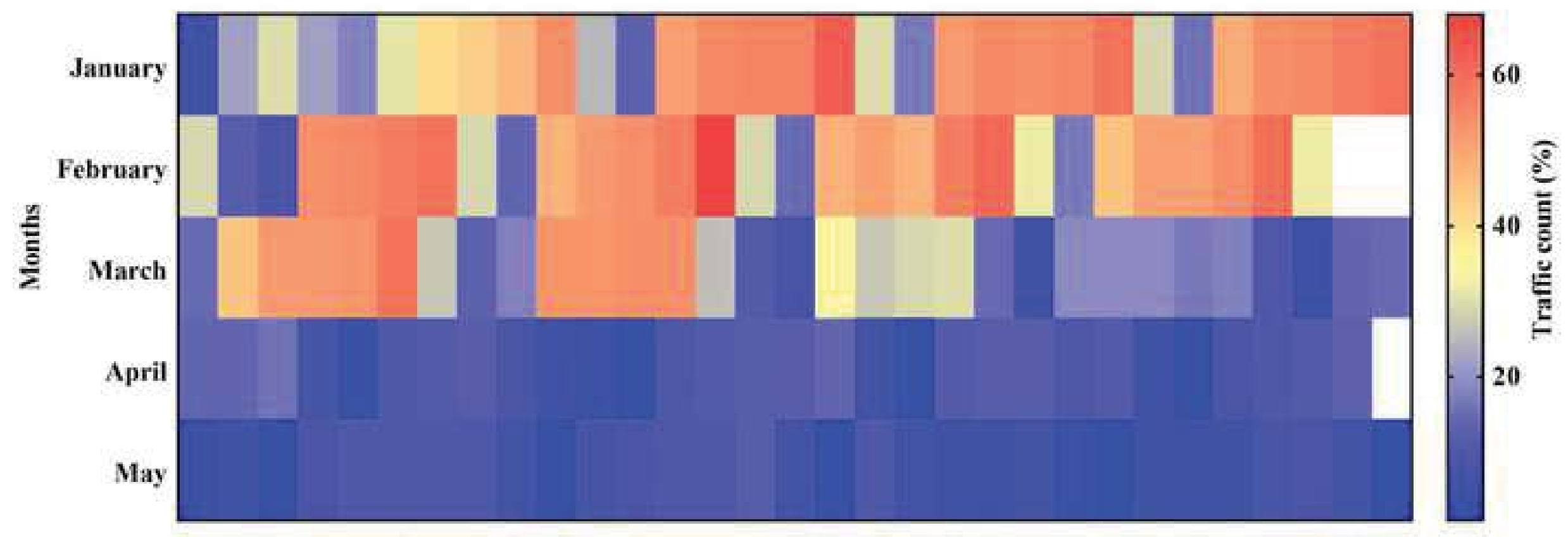

$\begin{array}{lllllllllllllllllllllllllllllll}1 & 2 & 3 & 4 & 5 & 6 & 7 & 8 & 9 & 10 & 11 & 12 & 13 & 14 & 15 & 16 & 17 & 18 & 19 & 20 & 21 & 22 & 23 & 24 & 25 & 26 & 27 & 28 & 29 & 30 & 31\end{array}$ Days (24 hour average)

\begin{tabular}{|l|l|l|l|l|l|l|l|}
\hline Period & & $\mathrm{PM}_{25}$ & $\mathrm{PM}_{10}$ & $\mathrm{CO}$ & $\mathrm{O}_{3}$ & $\mathrm{NO}_{2}$ & $\mathrm{SO}_{2}$ \\
\hline Lockdown & $\begin{array}{l}\text { Traffic } \\
\text { count }\end{array}$ & 0.14 & $0.33^{*}$ & $-0.29^{*}$ & -0.21 & $0.46^{* \%}$ & $0.30^{* \%}$ \\
\hline
\end{tabular}

$$
p<0.05^{*} ; 0.01^{*} ; 0.001^{*}
$$




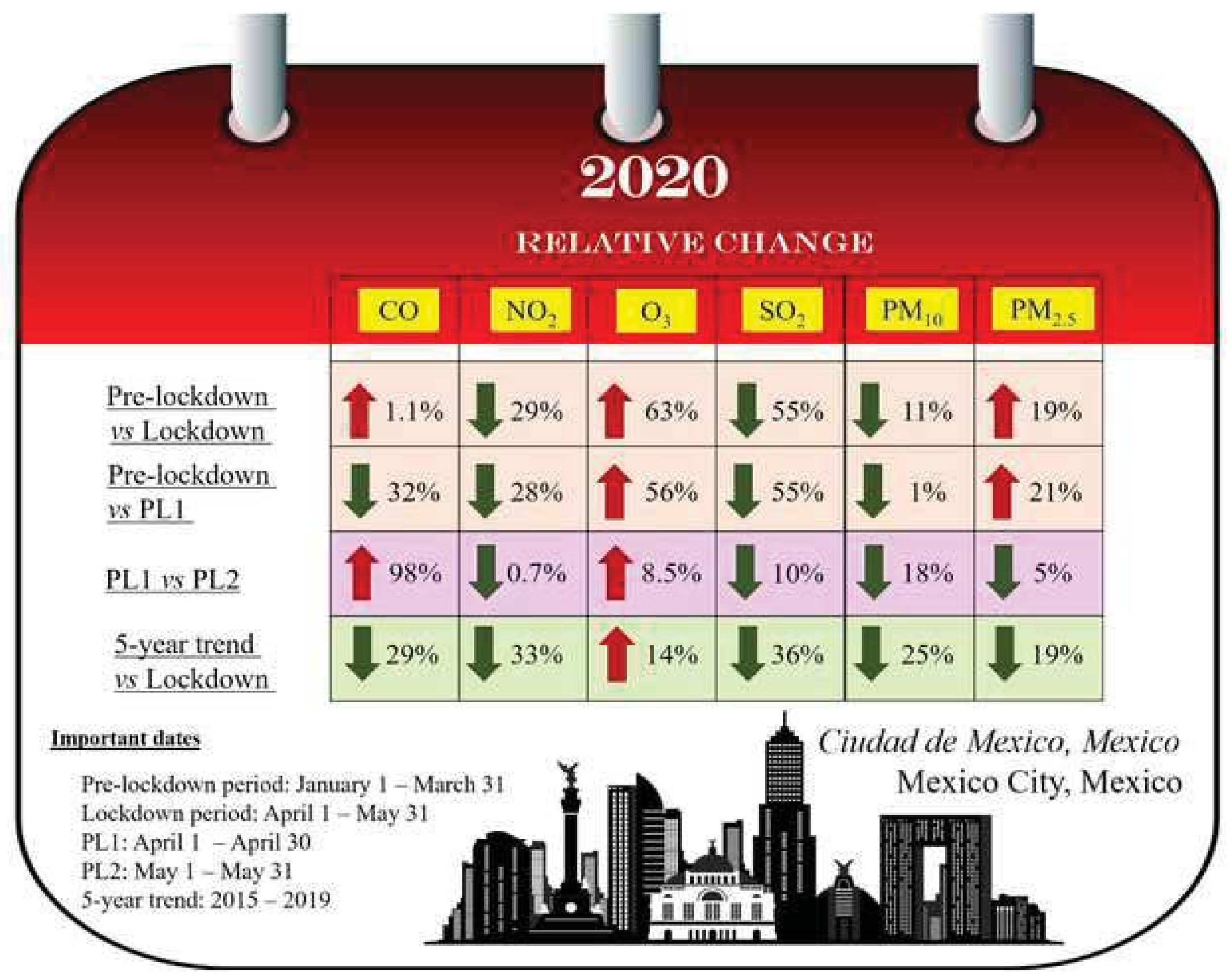


Figures
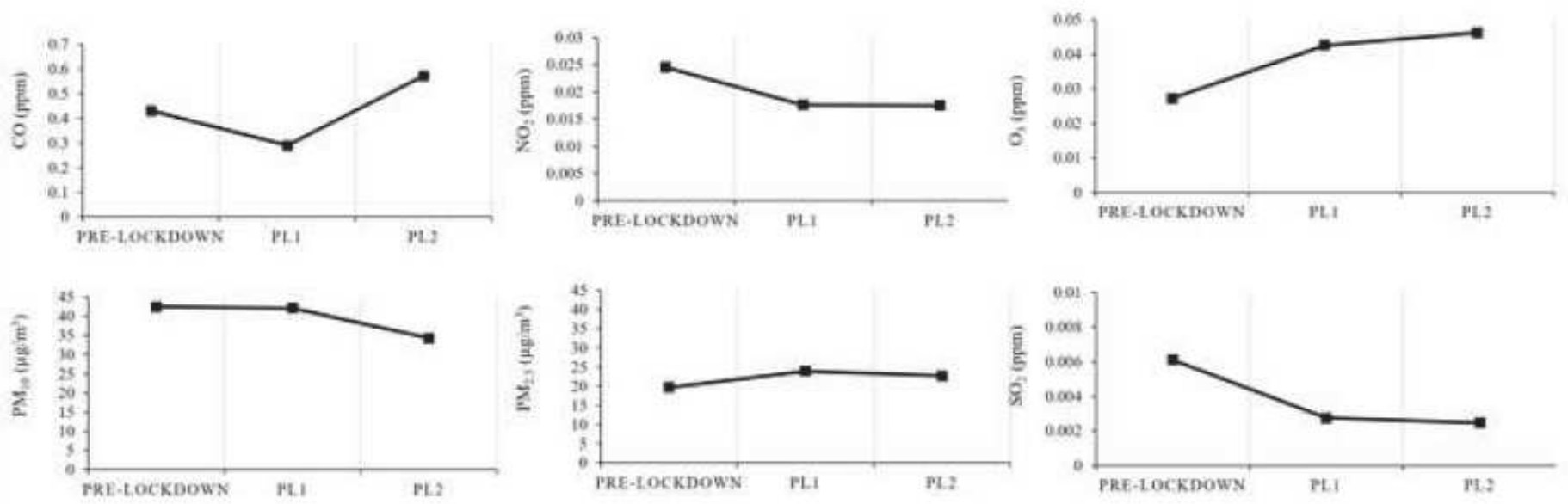

PRE-LOCKDOWN: January 1-March 31, 2020

PL1:April 1-April 30, 2020

PL.2: May 1-May 31, 2020

\section{Figure 1}

Average concentrations of air pollutants during the pre-lockdown and two different periods of partial lockdown (PL1 and PL2) in Mexico City (Mexico).

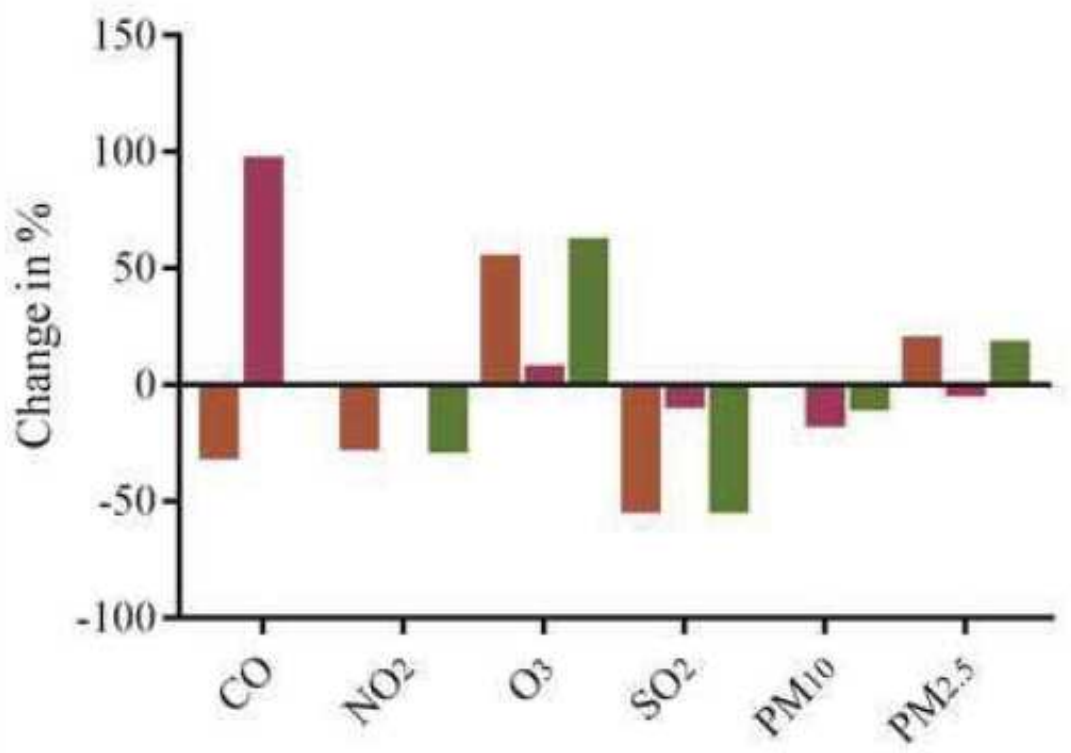


Figure 2

Bar chart representing the overall changes (\%) in air pollutants of Mexico City.

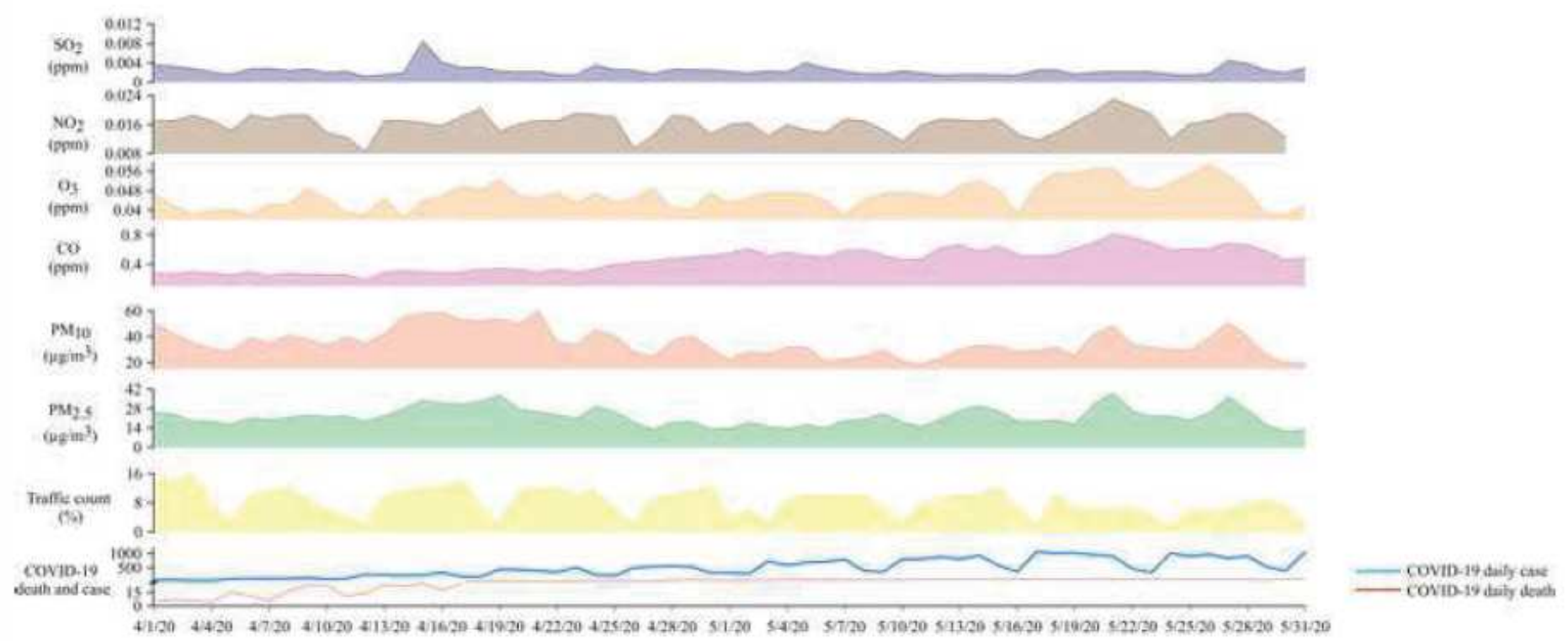

\section{Figure 3}

Daily trends of air pollutants, traffic counts and COVID-19 confirmed cases and deaths since the start of restrictions in Mexico City. 


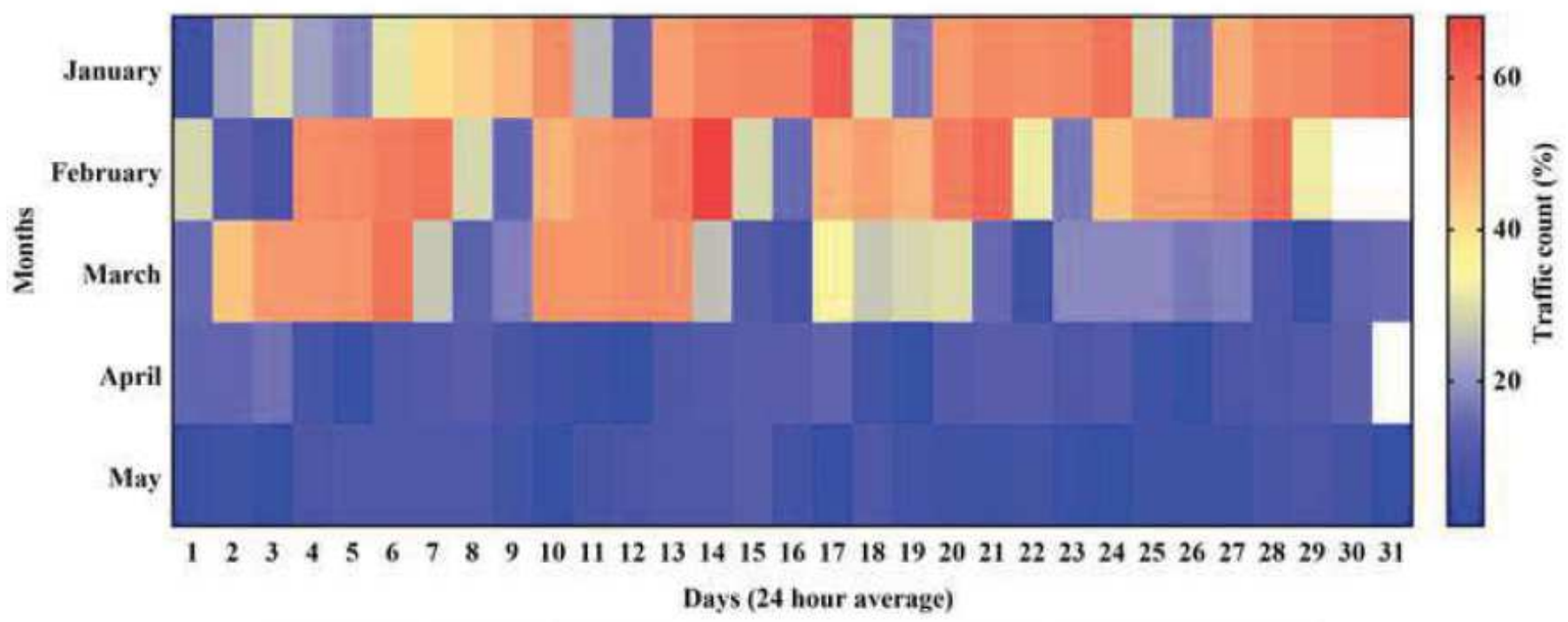

\begin{tabular}{|l|l|l|l|l|l|l|l|}
\hline Period & & $\mathrm{PM}_{25}$ & $\mathrm{PM}_{10}$ & $\mathrm{CO}$ & $\mathrm{O}_{3}$ & $\mathrm{NO}_{2}$ & $\mathrm{SO}_{2}$ \\
\hline Lockdown & $\begin{array}{l}\text { Traffic } \\
\text { count }\end{array}$ & 0.14 & $0.33^{*}$ & $-0.29^{*}$ & -0.21 & $0.46^{+}+$ & $0.30^{*}$ \\
\hline
\end{tabular}

$p<0.05^{*} ; 0.01^{*} ; 0.001^{t}$

Figure 4

Traffic counts for the period of January 1 - May 31, 2020 in Mexico City from the TomTom traffic database and the correlation between traffic count and air pollutants during the lockdown period. 